\title{
Det syriske Adams Testamente
}

Stud.theol. Peter Christensen, stud.theol. Stefan Kristensen, stud.theol. Amanda Norsker, stud.theol. Anders Larsen, ph.d.-stipendiat Kasper Siegismund, lektor Martin Ehrensvärd og lektor Søren Holst, Københavns Universitet

Abstract: The article presents a Danish translation of the oldest extant manuscript of the Syriac Testament of Adam. This manuscript comprises the two first sections (the Horarium and Prophecy) of the total of three sections usually described as making up this composite text. In addition to giving an introduction and translation, the article discusses key issues of the text's language and theology and aspects of its interpretation of the Garden of Eden story, such as the nature of the forbidden fruit, the future fate of Adam and its Christological implications.

Keywords: Testament of Adam - Cave of Treasures - Adam literature Syriac pseudepigrapha - theosis.

En kort syrisk tekst, som har fået navnet Adams Testamente (TestAd), kom til bibelforskeres kendskab, da et manuskript dukkede op i Vatikanbibliotekets orientalske samling i 1725, og blev første gang publiceret af Ernest Renan i $1853 .{ }^{1}$ Testamentet fandt ikke vej til den storartede danske udgave af De Gammeltestamentlige Pseudepigrafer, som E. Hammershaimb m.fl. besørgede i perioden 1953-76, og teksten synes i det hele taget at være blevet i nogen grad overset i den ivrige beskæftigelse med ikke-kanonisk, bibellignende litteratur, som blomstrede op fra midten af det 20. århundrede. Først i 1982 blev den genstand for omhyggeligere granskning i en amerikansk ph.d.studerendes hænder og året efter udgivet $\mathrm{i}$ en mere alment tilgængelig samling af Gammel Testamente-relaterede pseudepigrafiske tekster. ${ }^{2}$ Den anslås her til at stamme fra midten af det 3. århundrede e. Kr. (Robinson 1983, 990; jf. 1982, 151).

At teksten i genrehenseende hører til de gammeltestamentlige pseudepigrafer, ligger lige for. Det mest omfattende manuskript består af tre hoveddele: Et "Horarium" (kap. 1-2), her kaldet Timerne,

1. Ernest Renan, "Fragments du livre gnostique intitulé Apocalypse d'Adam, ou Pénitence d'Adam ou Testament d'Adam, publiés d'après deux versions syriaques”, Journal asiatique V, 2 (1853), 427-471.

2. Stephen Edward Robinson, The Testament of Adam. An Examination of the Syriac and Greek Traditions, SBL Dissertation Series 52 (Chico: Scholars Press 1982); "Testament of Adam", The Old Testament Pseudepigrapha, red. James H. Charlesworth (New York: Doubleday 1983-1985), bd. 1, 989-995. 
som opregner nattens og dagens timer og de skabte væsener og fænomener, hvis lovprisning er henlagt til hver enkelt time; en egentlig testamentetekst (kap. 3), ofte kaldet Profetien, hvor Adams sidste ord til sin søn Set er nedfældet, og som rummer både tilbageblik på Paradis og en gengivelse af Guds løfte til Adam om Kristi fremtidige gerning; og et Hierarki (kap. 4) over grupper af engle og himmelske kræfter. ${ }^{3}$ At teksten i sin nuværende skikkelse er af entydigt kristen herkomst, er lige så oplagt; den lægger sig hermed på linje med andre gammeltestamentlige pseudepigrafer som $\mathrm{fx}$ dele af De Tolv Patriarkers Testamenter, som også anvender formelt set gammeltestamentligt materiale og formsprog til at fremsætte kristne pointer, men adskiller sig i denne henseende fra dele af den øvrige adamlitteratur (se herunder), der kan tænkes at være af rent jødisk proveniens.

\section{Manuskript, palæografi, sprog og den litterære kontekst}

\section{Presentation af Manuskript $A$}

Det tilgængelige materiale for Test $A d$ på syrisk foreligger i tre såkaldte recensioner, det vil sige tre tekstudgaver, som er fordelt over otte konkrete manuskripter. Disse manuskripter stammer fra ca. det 9. til det 18. århundrede e. Kr., hvor Manuskript A fra ca. det 9. århundrede, også kendt som BM Add 14,624, udgør den ældst kendte version af teksten og er lagt til grund for den danske oversættelse, vi her fremlægger. Manuskriptet er skrevet på pergament og rummer Timerne for både natten og dagen og Profetien, mens Hierarkiet ikke er med. Man har i forskningen overvejet, hvorvidt Timerne og Profetien i Manuskript A udgør de originale versioner af TestAd, eller om de er baseret på et ældre hebraisk eller græsk forlæg (Robinson 1982, 135-37).

Grundlaget for sidstnævnte antagelse består i, at ét manuskript med græske fragmenter af Timerne fra det 16. århundrede, Paris 2419, indeholder navne for de forskellige timer skrevet med hebraiske bogstaver, omend selve navnene er græske (Robinson 1982, 105-07; 130). Tanken om en græsk original til Timerne vanskeliggøres af, at ingen græske fragmenter kan dateres tidligere end til det 15. århundrede, mens der af Profetien slet ingen græsk version er overleveret.

3. En nutidig materialfilologisk tilgang vil anfægte det rimelige i at se et abstrakt "værk" som det egentlige og de faktiske manuskripter blot som "vidnesbyrd" om dette. En sådan tilgang vil næppe regne Hierarkiet, der kun forekommer i ét af de otte syriske manuskripter, for en del af teksten. Vi har i det følgende koncentreret os om det ældste syriske manuskript, Ms A, og dermed om Timerne og Profetien. 


\section{Sproglige sertrek}

Den syriske tekst i Manuskript A er skrevet helt efter sprogets regler, og hverken Timerne eller Profetien virker mere influeret af græsk, end det syriske sprog allerede var i forvejen. Robinson bemærker i sin argumentation for, at Test $A d$ oprindeligt er skrevet på syrisk, at der optræder flere mulige syriske ordspil i Profetien 3,2; 3,3; 3,5. Således kan der i 3,2 foreligge et ordspil på గمo , der betyder "maddike", men som også kan angive et tidsrum. I 3,3 findes muligvis et ordspil

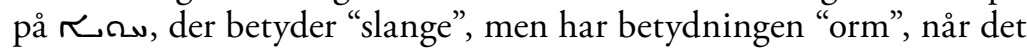
bruges anden gang - eftersom slanger ikke spiser mennesker. ${ }^{4}$ I 3,5

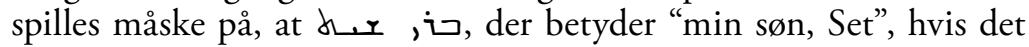

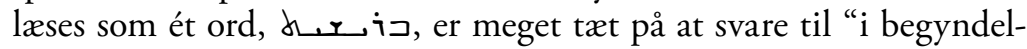
sen", حنَr (Robinson 1982, 142). Umiddelbart står kun den syriske tekst tilbage som mulig original, skønt det i princippet er muligt, at den har et græsk eller hebraisk forlæg.

\section{Paleografiske sartrek}

Skrifttypen i Manuskript A er Estrangela, den ældste syriske skriftype, men der er samtidig tydelige spor af den yngre skrifttype Serta for bestemte bogstaver - Mens alef vilkårligt skifter form fra det ældre $\kappa$ til det yngre 3 , er dalet og resh altid skrevet med Serta, $;$ og + . Enkelte gange mangler den diakritiske markør, så man ikke kan se forskel på de to bogstaver. Håndskriftens stil, som er identisk både for Timerne og Profetien, vidner om, at der højst sandsynligt er tale om den samme skriver for begge hoveddele af Manuskript A. Det betyder ikke, at han nødvendigvis er ophavsmand til dem begge, men i hvert fald, at han har set dem som sammenhængende dele. Der er dog en enkelt forskel med hensyn til ortografien - brugen af adskillelsestegnet " $:$ " er begrænset til Profetien med én undtagelse til sidst i Timerne. Normalt anvendes et andet adskillelsestegn i Timerne "." med samme betydning.

\section{Den littercere kontekst for Profetien}

Adams (eller Evas) "testamentetale" til Seth er en scene, vi kender fra de varierede og meget udbredte skrifter om Adams og Evas liv uden for Paradis og indtil deres død, den såkaldte 'primære adamlit-

4. Således Robinson (1982), 182. Ordet $\mathcal{L}_{\Omega}$ kan dog hverken ifølge PayneSmiths eller Sokoloffs ordbog betyde "orm", og meningen med udtrykket kan være, at mennesket iflg. Gen 3 skal blive til støv - som slangen ifølge samme passage skal spise. Et andet, ikke-filologisk, argument for at tanken om, at mennesket bliver slangemad, er af syrisk herkomst, er den selvsamme tankegangs forekomst hos Afrahat, Demonstrationes XXIII 3, jf. Peter Bruns, Aphrahat: Unterweisungen I-II, Fontes Christiani 5/1-2 (Freiburg o.a.: Herder 1991), 528. 
teratur'. De to bedst kendte versioner er den græske Moses' Apokalypse (ApkMos) og den latinske Adams og Evas Liv (VitaAd). Profetien i Test$A d$ placerer sig først og fremmest i fortælleuniverset fra den primære adamlitteratur, og scenen har beholdt en del af sin sædvanlige narrative kontekst, hvor Adam ligger som en døende, gammel mand. Adams død og begravelse er også her et vigtigt tema, hvor himlen slukker sine lys (VitaAd 46, i syv dage; ApkMos 36), og det er englene og de himmelske magter, der begraver Adam (VitaAd 48; ApkMos 40).

I den forbindelse beskrives også Adams sjæls opfart til himlen, idet Guds barmhjertighed vil komme over Adam ikke bare ved tidernes ende, hvor hans legeme skal opstå, men også ved hans død, hvor hans sjæl går til en himmelsk mellemtilstand (ApkMos 37; VitaAd 47). Det kan være denne forestilling, der gemmer sig bag den tilsyneladende uoverensstemmelse i TestAd 3,3, nemlig at der vil komme barmhjertighed over Adam "efter en kort tid", og at Gud ikke vil lade ham "sygne hen i Dødsriget". Gud forklarer nemlig samtidig, at Adams guddommeliggørelse vil ske "efter mange år" $(3,3)$ på et tidspunkt efter kristusbegivenheden $(3,4)$, som vil ske "efter tiderne" $(3,1)$, hvilket må være mindst 6000 år $(3,5)$. Altså ikke ligefrem "en kort tid".

Profetien bringer også et interessant begreb på banen; "skattehu-

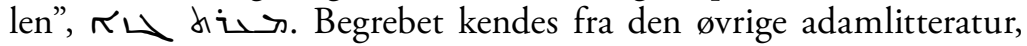
først og fremmest fra skriftet Skattehulen, men også et andet skrift, der lægger sig tæt opad, kaldet Adams Kamp. ${ }^{5}$ Det drejer sig om en hule, Adam indrettede som bedehus og bolig efter sin uddrivelse fra Paradis for at have et sted at tilbede Gud, og hvor han opbevarer "skattene", nemlig det guld, røgelse og myrra, som han har fået skænket af en engel. I TestAd 3,6 hører vi, at de tre vise mænd henter disse ting i skattehulen, inden de bringer dem til Guds søn i Betlehem, ligesom også selve "testamentet" nedfældes af Set og placeres i hulen. I VitaAd 51,3 nedfældes Adams og Evas "testamenter" af Set på tavler af sten og ler.

Hulen er også det sted, hvor Adam begraves efter sin død i de to skrifter, og de harmoniserer forskellige traditioner omkring Adams gravsted, idet fortællingens narrative skelet er beretningen om, hvordan Adams døde legeme transporteres fra skattehulen nær paradisets

5. Kendt under flere forskellige navne: A. Dillmann, Das christliche Adambuch des Morgenlandes (Göttingen: Dieterich 1853); Ernst Trumpp, Der Kampf Adams (gegen die Versuchungen des Satans), oder: Das christliche Adambuch des Morgenlandes aethiopischer Text, verglichen mit dem arabischen Originaltext (München: Verlag der Akademie der Wissenschaften 1880); S.C. Malan, The Book of Adam and Eve: Also called the Conflict of Adam and Eve with Satan, a book of the early Eastern Church (London: Williams and Norgate 1882) o.a. 
have, med ind i Noas ark, og begraves under Golgata. ${ }^{6}$ Traditionen med Adams grav under Golgata, som vi hører om først hos Origenes (kommentar til Matt 27,33), spiller en afgørende rolle i Skattehulen og Adams Kamp, idet disse skrifter har et stort fokus på det geografiske område med Golgata og Jesu grav som jordens centrum, hvor Gud vil virke sin frelse (Sl 74,12; jf. tempelbjerget i jødedommen og Gravkirken i kristendommen), og især Skattehulen udfolder AdamKristus-typologien på baggrund af dette forhold. Der optræder i denne forbindelse en "ontologisk" frelseslære, ifølge hvilken Adams frelse vil ske i kraft af et adamslegemes (dvs. et menneskelegemes) lidelse, død og opstandelse, ${ }^{7}$ og denne frelseslære - som er helt fraværende i den primære adamlitteratur - ser ud til også at være grundlaget for Adams frelse i TestAd (se kommentardel om Adam nedenfor).

Det nærmere slægtskab mellem TestAd, Skattehulen og Adams Kamp er uklart, og det har særligt været diskuteret, hvorvidt TestAd er litterært afhængig af Skattehulen, hvilket Robinson med baggrund i blandt andet A. Götze, Die Nachwirkung der Schatzhöhle, mener at kunne afvise. De to tekster optræder sammen i flere manuskripter, men der kan på denne baggrund næppe konkluderes noget litterært afhængighedsforhold imellem dem (Robinson 1982, 18-20; 30).

\section{Oversættelse ${ }^{8}$}

Derpå:9 Vor far Adams testamente.

1,1 Nattens første time: Dæmonernes taksigelse. Og i den time gør de ikke fortræd, og de gør ikke nogen skade mod mennesket.

1,2 Den anden time: Duernes taksigelse.

6. Ifølge den primære adamlitteratur blev Adam begravet i det jordiske paradis (ApkMos 40,6; VitaAd 48,3), hvilket minder mere om TestAd, mens en jødisk tradition placerer ham i 'Patriarkernes Grav', Makpelas hule i Hebron (BerR 58,4; PRE 20; jf. Gen 25,9).

7. Skattehulen 5,8-13 (efter inddelingen i Alexander Toepel, "The Cave of Treasures", Old Testament Pseudepigrapha: More Noncanonical Scriptures, bind 1, red. Richard Bauckham m.fl. (Grand Rapids /Cambridge: Eeerdmans 2013), 531-84); Adams Kamp, bog I, kap. 14-15 (efter inddelingen i Malan 1882).

8. Oversættelsen er foretaget fra den fotografiske gengivelse af manuskript A i Robinson (1982), 52-66. Især mhp. varianter i den øvrige manuskripttradition er inddraget den seneste trykte tekstudgave, Michael Kmosko, "Testamentum patris nostri Adam”, Patrologia Syriaca. Pars Prima: Ab initiis usque ad annum 350. Tomus secundus, red. René Graffin (Paris: Firmin-Didot 1907), 1307-1360.

9. Det syriske בnל indleder typisk ikke blot et nyt kapitel eller hovedafsnit, men også et nyt selvstændigt skrift i en kodeks. 
1,3 Den tredje time: Fis[k]enes, ildens og all[e] de nedre dybs taksigelse.

1,4 Den fjerde time: Serafernes helli[g]sang. Således hørte jeg, før jeg syndede, lyden af deres vinger $i$ Paradis, når seraferne baskede med dem til lyden af deres helligsang, men efter jeg overtrådte loven, har jeg ikke hørt denne lyd.

1,5 Den femte time: Vandets taksigelse, det, som er oven over himlen.

Således hørte jeg og englene lyden af kraftige bølger, som af et tegn blev ansporet til at lovprise skaberens ære.

1,6 Den sjette time: Dannelsen af skyer og stor frygt midt om natten. 1,7 Den syvende time: Synet af vandets kræfter, når det sover. Og i den time tages vandet op, og Guds præst blander hellig olie i det og salver dem, som trænger, og de får hvile.

1,8 Den ottende time: Opblomstri(ng $)^{10}$ af jordens græs, når duggen falder fra himlen.

1,9 Den niende time: Kerubernes taksigelse.

1,10 Den tiende time: Menneskenes taksigelse og åbning af himlens port, hvor alle levendes bønner går ind og tilbeder og går ud. Og i den time bliver alt, som et menneske beder om fra Gud, givet til ham, når seraferne og hanerne basker med deres vinger.

1,11 Den ellevte time: Glæde på hele jorden, når solen stiger op fra Paradis og skinner på skabningerne.

1,12 Den tolvte time: Forventning om r[øgels]e og [s]tilhed, som hviler [over] alle ildens [og vinden]s ordener, indtil [all]e præsterne fremsætter røgelsen til hans guddommelighed, og så slippes alle de himmelskes kræfter løs.

Nattens timer er fuldendte. Derpå: Dagens timer.

2,1 Dagens første time: De himmelske kræfters påkaldelse.

2,2 Den anden time: Englenes bøn.

2,3 Den tredje time: Fuglenes taksigelse.

2,4 Den fjerde time: Dyrenes taksigelse.

2,5 Den femte time: Taksigelse over himlen. ${ }^{11}$

2,6 Den sjette time: Kerubernes taksigelse - dem, som går i forbøn for vores menneskeligheds uret.

2,7 Den syvende time: Indgang og udgang hos Gud, hvor alle levendes bønner går ind og tilbeder og går ud.

2,8 Den ottende time: Ildens og vandets taksigelse.

2,9 Den niende time: Englenes bønfaldelse - dem, som står foran storhedens trone.

10. De sidste to bogstaver synes udeladt ved en skrivefejl.

11. I nattens femte time omtales vandet, som er oven over himlen. Det er der givetvis også tale om her. 
2,10 Den tiende time: Vandets hjemsøgelse, hvor ånden stiger ned og svæver over vandet og over kilderne. Og hvis (ikke) ${ }^{12}$ Herrens ånd steg ned og svævede over vandet og over kilderne, ville menneskene blive skadet. Og alle, som dæmonerne så, ville de skade. Og i den time tages vandet op, og Guds præst blander hellig olie i det og salver dem, som trænger, og de bliver sunde og raske.

2,11 Den ellevte time. De retfærdiges jubelråb og glæde.

2,12 Den tolvte time, som er aftenen. Menneskenes bønfaldelse om velvilje hos Gud, altings Herre.

3,1 Adam sagde til sin søn, Set: "Du har hørt, ${ }^{13}$ min søn, at Gud vil komme til verden efter tiderne. Og han vil blive undfanget af en jomfru og iklæde sig et legeme og blive født som et menneske og vokse op som et barn og gøre tegn og undere på jorden: Han vil vandre på havets bølger, irettesætte vindene, og de vil blive rolige. Han vil give tegn til bølgerne, og de vil stå stille. Han vil åbne de blindes øjne, rense de spedalske, få de døve til at høre, de stumme vil tale, de krumbøjede vil han rette ud, de lamme vil han gøre stærke, de fortabte vil han finde. Han vil uddrive onde ånder og kaste dæmoner ud.

3,2 Angående dette sagde Gud til mig i Paradis, da jeg havde plukket af frugten, hvor døden var skjult: 'Adam, Adam, frygt ikke! Du $ø$ nkede at blive en gud. En gud vil jeg gøre dig til. Dog ikke nu, men efter mange år. Jeg vil udlevere dig til døden, og maddiker og orme vil fortære dit legeme'.

3,3 Og jeg svarede og sagde til ham: 'Hvorfor, min herre?'. Og han sagde til mig: 'Fordi du hørte på slangens ord, skal du og dit afkom være føde for slangen. Og efter en kort tid vil der være barmhjertighed over dig, ${ }^{14}$ fordi du er skabt i mit billede. Og jeg vil ikke lade dig sygne hen i Dødsriget. For din skyld vil jeg blive født af jomfru Maria. For din skyld vil jeg smage døden, og jeg vil gå ind i de dødes hus. For din skyld vil jeg skabe en ny himmel, og dine efterkommere vil jeg lade herske i den. ${ }^{15}$

$3,4 \mathrm{Og}$ efter tre dage, hvor jeg vil være inde i graven, vil jeg oprejse det legeme, som jeg har iklædt mig fra dig. Og jeg vil sætte dig på

12. Der mangler tilsyneladende en negation i ms. A. Den er der i ms. F og i den græske, arabiske og etiopiske version.

13. Ms. B har "jeg har hørt". Ms. F har "hør på mig”.

14. Kan også oversættes "på grund af dig” frem for "over dig”, hvorved det er menneskene som sådan, der vil blive vist barmhjertighed.

15. En anden mulig oversættelse er: "og dine efterkommere vil jeg være indsat over". Det forudsætter en sætningsopbygning med foransat objekt, der genoptages med et pronominalsuffiks til sidst ("og dine efterkommere - jeg vil være indsat over dem”). 
højre side af min guddommelighed, og [j]eg [vil] g[øre] (dig) $)^{16}$ til en gud, ligesom $[\mathrm{du}]$ øns[kede]. Og jeg vil tage gaven fra $\mathrm{t}[\mathrm{ræet}]^{17}$ og gen[oprette $]^{18}$ dig og dit afkom, for det e[r] himlens retfærdighed'.

3,5 Du har hørt, min søn Set, ${ }^{19}$ at der skal komme en oversvømmelse, og den skal rense hele jorden på grund af din bror Kains døtre - ham, som på grund af begær til din søster Lebuda dræbte din bror Abel, fordi synderne var blevet skabt ved din mor Eva. Og efter oversvømmelsen skal verdens form vare ved i 6000 år, og så skal dens ende komme".

3,6 Og jeg, Set, nedfældede dette testamente, og min far døde, og de begravede ham øst for Paradis over for den første by, som blev bygget på jorden, hvis navn var Enok. Og Adam blev fulgt af engle og himlens hærskarer, fordi han var skabt i Guds billede. Og solen og månen blev formørket, og der var mørke i syv dage. Og vi forseglede testamentet og lagde det i skattehulen med offergaver, som Adam havde taget med ud fra Paradis: Guld og myrra og røgelse. Og kongesønnerne, vismændene, vil komme og tage dem og bringe dem til Guds søn til Judæas Betlehem, til hulen.

$\mathrm{Slu}[\mathrm{t}]$ på vor far Adams testamente.

\section{Kommentar til udvalgte temaer}

\section{Timerne}

Timerne er en opremsning af natten og dagens i alt 24 timer med dertil hørende handlinger, udført af dyr, engle, elementer og mennesker. Denne fastsættelse af en daglig rytme med bestemte handlinger til bestemte tider minder mest af alt om tidebønner, men adskiller sig herfra ved at være mere deskriptiv end normativ, ved at indeholde alle døgnets timer og ved ikke kun at beskrive menneskelige handlinger.

Der er ikke umiddelbart noget system at finde i timerne og den handling, der følger med. Kun i den femte og ellevte time er der

16. Ms. B har på dette sted et selvstændigt @. Det må i Ms. A være underforstået eller udeladt ved en fejl; der er i lakunen næppe plads til, at verbet kan have haft pronominalsuffix.

17. Der er en lakune her, hvor kun det første bogstav, alef, kan ses. Kmosko foreslår "træ" ( $\sim \mathcal{L})$, mens Robinson siger "Gud" ( $\kappa m \downarrow \kappa)$.

18. Kan også oversættes "lade vende tilbage" måske med henvisning til de dødes opstandelse eller venden tilbage til Paradis.

19. Hvis man læser "min søn Set" som ét ord på syrisk, bliver det til "i begyndelsen”, jf. Gen 1,1. Dette kunne tale for syrisk som originalsproget til i hvert fald dette sted (Robinson 1982, 63). 
paralleller mellem natten og dagen, ${ }^{20}$ men så få overensstemmelser kan lige så godt være tilfældigheder. Selvom der ikke er et decideret mønster at finde i døgnets timer, er de dog ikke alle sammen placeret tilfældigt; på flere punkter passer indholdet med et døgn, der starter ved solnedgang, og således er der en logik bag placeringen af nogle af versene. ${ }^{21}$ Nattens sjette time, hvor der er stor frygt, passer nogenlunde med midnat $(1,6)$, i nattens tiende time basker hanerne med vingerne lige ved morgengry $(1,10)$, og solen går op i den ellevte time $(1,11)$. Også bønner kan passe ind i dette skema: Den jødiske bøn Shema bliver sagt ved det første og sidste dagslys og kan dermed passe med, at menneskets taksigelse finder sted, når himlens port åbnes for bønner i nattens tiende time $(1,10)$, altså kort før solopgang, og med menneskets bønfaldelse om velvilje i dagens tolvte time $(2,12)$, lige inden solnedgang (Bauckham 2008, 401-402). Også 1,7; 1,12 og 2,10 , der omhandler forskellige præstelige gerninger, kan vidne om faste tidspunkter for disse handlinger.

Hele tolv af natten og dagens timer omhandler taksigelse. Kun én gang går subjektet for taksigelsen igen (keruber i 1,9 og 2,6), men ellers er det forskellige væsener, der hver gang gør taksigelse. Det er underforstået i alle disse vers, at det er Gud der takkes, hvilket bevidnes i taksigelsernes tætte forbindelse til Salme 148. Salmen indledes med "Lovpris Herren..." og derefter opremses alt, hvad der skal lovprise Herren. Den underlige sammensætning af fisken og de nedre dybder,

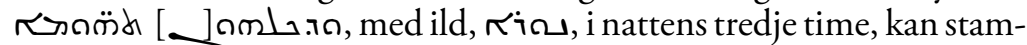
me fra Sl 148,7-8, hvor havdyr, nedre dybder, Nonm̈d nman, og ild, గiऽ, også er kombineret i en lovprisning. I Sl 148,4 skal vandet over himlen lovprise, et subjekt, der er gentaget i nattens femte time. Men lige netop vandet over himlen leder også tankerne hen på Gen 1,6-8; og Timerne er, ligesom lovprisningssalmen, fyldt med referencer til skabelsesberetningen i Gen 1. En af de tydeligste af disse er dagens tiende time, hvor ånden stiger ned og svæver over vandet,

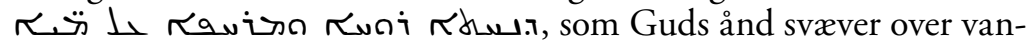

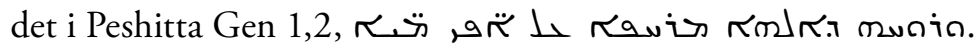

Referencerne til Gen 1 og forbindelsen til Sl 148 gør det tydeligt, at de dyr, himmelske væsener og elementer, der indgår i Timerne, er et udtryk for hele skaberværket. Taksigelserne er med andre ord hele ska-

20. Dagens femte time $(2,5)$ er stort set en gentagelse af første sætning i nattens femte time $(1,5)$, bortset fra ordet vand, $\pi$, som højst sandsynligt er underforstået. Natten og dagens ellevte time handler begge om glæde.

21. At Timerne behandler natten før dagen, skyldes højst sandsynligt den gamle jødiske tradition, at døgnet starter ved solnedgang, jf. Richard Bauckham, The Jewish World Around the New Testament, WUNT 233 (Tübingen: Mohr Siebeck 2008), 394 (note 10). 
berværkets taksigelse til skaberen. Ideen med at opremse alle døgnets timer, selvom kun nogle af dem beskriver menneskelige handlinger, kan være at sætte menneskets gudsdyrkelse ind i et større perspektiv. Når en taksigelse eller anden handling fra noget skabt knyttes til hver enkelt time, gøres menneskets gudsdyrkelse, med bønner og præstelige handlinger, til en del af skaberværkets daglige rytme, og den får med andre ord en plads i hele skaberværkets hyldest til skaberen.

Noget af det mest interessante og obskure i Timerne er de præstelige handlinger i 1,7 og 2,10. I 1,7 er der "syn af vandets kræfter, mens det sover". Hvem der ser vandets kræfter, fremgår ikke af teksten, men kan måske tænkes at være et generelt "man" eller præsterne, der nævnes umiddelbart efter. Præsterne tager vandet op, og blander det sammen med olie, og blandingen bliver brugt til salvning. ${ }^{22}$ Den samme sammenblanding sker også i 2,10, men her er en længere indledende forklaring. Glosen, som vi har oversat med "hjemsøgelse", గhoiณ $\infty$, kan betyde "tilsyn" eller "besøg", men kan også have den mere generelle betydning handling. Den næste sætning handler om ånden, der svæver over vandet, og det forekommer nærliggende, at det er ånden, der fører tilsyn med vandet, eller hjemsøger vandet. Ånden gør tilsyneladende noget ved vandet i denne handling, som beskytter menneskene mod at blive skadet af dæmoner. Her refereres måske til dæmonerne fra 1,1, så de syge salves her sidst på dagen, for at dæmonerne ikke skal skade dem i nattens første time. Selvom der er ligheder mellem 1,7 og 2,10, og det er dem, "der trænger", der bliver salvet, er resultatet i 1,7, at de får hvile, mens de i 2,10 bliver sunde og raske. Det tyder på, at der er tale om forskellige "patienter". Om natten kan der være tale om dem, der er døende, mens det om dagen kan være de almindeligt syge.

Timerne synes ikke umiddelbart at have en sammenhæng med Profetien, der følger efter. Der er ikke noget entydigt kristent indhold i Timerne, hvorimod Profetien er fyldt med tydelige referencer til Det Nye Testamente. Derudover er de to dele af Adams Testamente meget forskellige, og overgangen imellem de to tekster virker ikke naturlig, men springer fra en direkte tale til "Adam sagde...". Af disse grunde er det oplagt, at Timerne er skrevet uafhængigt af Profetien og senere blevet brugt som indledning til denne (Robinson 1982, 156-158).

22. Måske er der tale om en helbredende olie fra barmhjertighedens træ, der skal salve mennesket; jf. "Adams og Evas Liv" og "Mose Apokalypse", jf. E. Hammershaimb, "Adamsbøgerne", De gammeltestamentlige pseudepigrafer, red. Erling Hammershaimb m.fl. (København: Det Danske Bibelselskab 22001), 509-47; M.D. Johnson, "Life of Adam and Eve", The Old Testament Pseudepigrapha, red. James H. Charlesworth (New York: Doubleday 1983-1985), bd. 2, 249-95 (255-56). 
Der er dog også en sammenhæng mellem de to tekster. Først og fremmest har de samme fortæller. Timerne indledes ikke med "Adam sagde...", ligesom Profetien gør, men det er alligevel tydeligt, at Adam er fortælleren, fx i 1,4 "Således hørte jeg, før jeg syndede, lyden af deres vinger i Paradis...". Beskrivelsen her af Adams tid i Paradis inden syndefaldet, sammen med de mange referencer til Gen 1, gør også Timerne til en narrativ optakt til Profetien, der tager udgangspunkt i Adams liv efter syndefaldet, idet han taler til sin søn, Set. Desuden omtaler Adam også et tidspunkt, hvor han havde syndet, men dog stadig var i Paradis $(3,2)$. Også Eva, Kain og Abel er nævnt i Profetien $(3,5)$. Timerne henviser altså til Gen 1, mens Profetien fortsætter med 2-4 (Robinson 1982, 145). Derudover er der muligheden for, at Timerne trækker på Hebræerbrevet, som Profetien også har tydelige forbindelser til (jf. herunder).

Den mulige forbindelse til den nytestamentlige skrifttradition gør det svært at afgøre om Timerne oprindeligt er skrevet i en jødisk eller kristen tradition, ${ }^{23}$ men det er tydeligt, at det i sin nuværende form må ses som sammenhængende med Profetien og dermed være en del af et skrift fra en kristen tradition.

\section{Nytestamentlig sprogbrug i Timerne?}

I tilknytning til spørgsmålet om en oprindeligt jødisk eller kristen herkomst for Timerne er det relevant at spørge, om der i Timerne, ud over de oplagte allusioner til Gen og Salmerne, findes spor af nytestamentlig sprogbrug. To mulige referencer kommer på tale. Det første sted er ved dagens niende time, hvor englene står "foran Guds storheds trone", مس.מ حחוס. herunder de gammeltestamentlige apokryfer, findes "Guds storheds trone" kun i to tekster: Vis 9,8 og Heb 8,1. I Vis beder Salomo til, at Visdommen må drage ud fra tronen, mens det i Heb er Jesus som

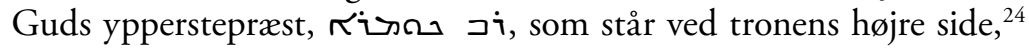

23. Der er argumenter for begge muligheder: De to bønner i 1,10 og 2,12, som kunne være den jødiske bøn Shema, og døgnets start ved solnedgang taler for en oprindelig jødisk baggrund. Man har også fremhævet lighedspunkter mellem Timerne og en tidlig jødisk liturgisk tekst, "Sange til Sabbatsofferet" fra Qumran (Stephen E. Robinson, "The Testament of Adam and the Angelic Liturgy", Revue de Qûmran 12 (1985), 105-110). De mulige referencer til NT og præsternes helbredende evner i 1,7 og 2,10, som ikke ellers er set i den antikke jødedom, kan tale for en kristen baggrund (jf. Bauckham (2008), 411).

24. Ordet حـר betyder "præst" i neutral forstand på trods af, at den hebraiske ækvivalent כפר i GT udelukkende bruges til at beskrive afgudernes præster. Derfor er det ikke af større betydning, at et helt andet ord for præst, حس حس, bruges i niende time, idet حصد ikke har negative konnotationer på syrisk, og de to udtryk altså er mere eller mindre synonyme. 
hvilket er interessant i forhold til dagens tiende time, som netop er det andet mulige sted i Timerne, hvor kristne traditioner kunne skinne igen-

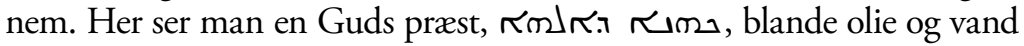
sammen for at "salve dem, som trænger ( sunde (s) og raske". Kombinationen af disse gloser genfindes én

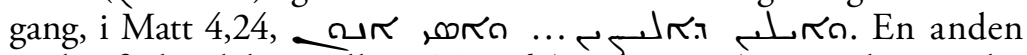
mulig forbindelse mellem TestAd $(2,9$ og 2,12) og Heb er ordet rharad, bønfaldelse, som i NT-Peshitta forekommer én gang, nemlig i Heb 5,7. Nytestamentlige allusioner forekommer naturligvis hyppigere i Profetien, ${ }^{25}$ men alt i alt forekommer det sandsynligt, at også Timerne i den form, som man finder dem i Manuskript A, trækker på nytestamentlige traditioner og måske særligt på Hebræerbrevet; det er dog vigtigt at huske, at den syriske litteratur er så omfangsrig, at GT og NT alene ikke kan give det fulde billede af, hvorfra TestAd eventuelt har ladet sig inspirere.

\section{Den forbudte frugt}

I Robinsons recension 2 findes der efter Adams gengivelse af Guds løfte om guddommeliggørelse en bemærkelsesværdig passage, hvor Set spørger Adam, hvad det var for en frugt, han spiste af i Paradis:

Og jeg, Set, sagde til min far Adam: "Hvad er navnet på den frugt, du spiste af?". Han sagde til mig: "Det var figenen, min søn, for gennem den dør, som døden kom ind ad over mig og ti ${ }^{26}$ alle mine efterkommere, skal livet komme ind til mig og mine børn [...]".

Denne tanke om figenen som den forbudte frugt findes også i et andet pseudepigrafisk Adamskrift, Moses' Apokalypse 20,4-5. Selve idéen er i og for sig oplagt ud fra den kanoniske beretning selv, eftersom den eneste træsort, der specifikt bliver nævnt i fortællingen, er figenen (som Adam og Eva laver "tøj” af i Gen 3,7). Der findes også flere steder i den rabbinske litteratur, hvor den samme tanke udtrykkes, sammen med andre forslag til, hvad det kunne være for et træ. Ifølge Talmud Bavli Berakot 40a mente Rabbi Meir, at der måtte være tale om en vinstok:

25. Og forbindelsen til Heb er her endnu tydeligere: At Jesus "iklæder sig et legeme",

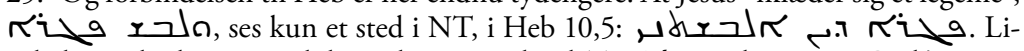
geledes er der kun ét sted, hvor der svarende til TestAd 3,3 tales om, at Gud/Kristus

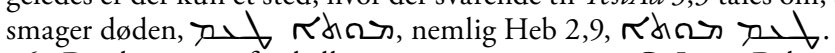

26. Der bruges to forskellige præpositioner i ms. C. I ms. D bruges den samme ("over") to gange. 
For det er kun vin, der bringer klageråb over mennesket. Som det er sagt (Gen 9), "og han drak af vinen og blev fuld...". Rabbi Nehemias sagde, at det var et figentræ, for ved det, som de blev ødelagt ved, kom de i orden igen. Som det er sagt (Gen 3), "og de syede figenblade sammen...”. Rabbi Juda sagde, at det var hvede, for barnet kan ikke kalde "far" og "mor", før det smager smagen af korn. ${ }^{27}$

Et lignende udsagn findes i Sanhedrin 70b i en anden sammenhæng, og samme idéer findes også i Pesikta Rabbati 42 og Genesis Rabbah 15,7. I sidstnævnte tekst er der også et forslag om, at det var en etrog (en slags citrusfrugt), og en eventuel indvending mod hvede som frugten fra træet imødegås med en påpegning af, at hveden i haven selvfølgelig var høj som Libanons cedertræer! Der tilføjes endda et par forslag til, hvilken sort af figner der kunne være tale om, men dertil indvendes, at det slet ikke er meningen, at vi skal vide, hvilken frugt det var, når Gud nu ikke har åbenbaret det i skriften.

I disse rabbinske tekster henvises der altså også til tanken om, at en form for genoprettelse kommer igennem det, som bragte faldet - men hvordan hænger det sammen med det, der siges i TestAd om, at livet skal komme gennem figentræet? Er der noget i den kristne fortælling, der lader figner spille en sådan rolle? I evangelierne findes som bekendt Jesu forbandelse af figentræet i forbindelse med tempelrensningen, hvor figentræet kommer til at symbolisere templet og den form for jødedom, som repræsenteres af Jesu modstandere (Mark 11,1226). Her kan tanken om figenen som syndens frugt give en ekstra nuance til læsningen - så bliver symbolet endnu voldsommere, idet Jesu modstanderes vildfarelser så knyttes sammen med den oprindelige overtrædelse af Guds bud. Det kan imidlertid næppe være denne historie om figenforbandelsen, der danner baggrund for udsagnet $\mathrm{i}$ TestAd - for her skal figentræet spille en positiv rolle.

I stedet kan man måske knytte an til en tradition, som findes i noget af den øvrige Adam-litteratur ( $\mathrm{fx}$ Adams og Evas Liv/Moses' Apokalypse). Her fortælles om Sets færd til Paradis for at få fat i livets olie, der kan helbrede den døende Adam. I en senere bevidnet tradition vender Set tilbage med "a twig or seeds from which grew the tree that eventually supplied the wood for the cross of Jesus". ${ }^{28}$

27. Det bemærkes, at "hvede" og "synd” ligger lydligt tæt på hinanden på hebraisk. 28. Johnson (1985), 255-56. Den nok tidligste bevidnelse af denne tradition findes ca. 1170 i Rationale divinorum officiorum af Johannes Beleth, i afsnittet "de exaltatione s. crucis”. Det relevante tekststykke findes citeret hos Wilhelm Meyer, „Die Geschichte des Kreuzholzes vor Christus“, Abhandlungen der philosophisch-philologischen Classe der Königlichen Bayerischen Akademie der Wissenschaften 16 (1882), 103-166 (115-116). Her nævnes det også, at denne historie er blevet indflettet i visse 
En bagvedliggende tanke i stil med dette kunne være en måde at forstå udsagnet i TestAd recension 2. Endelig kan man henvise til Det Gamle Testamentes beskrivelse af endetidens salighed, hvor enhver skal sidde under sin vinstok og sit figentræ (f.eks. Mika 4,4).

\section{Adam}

I vers 3,4 forklarer Gud, hvordan løftet til Adam vil blive opfyldt: "Og efter tre dage, hvor jeg vil være inde i graven, vil jeg oprejse det legeme, som jeg har iklædt mig fra dig. Og jeg vil sætte dig på højre side af min guddommelighed, og jeg vil gøre dig til en gud, ligesom du ønskede." Passagen ser ud til at gøre Adam til den ophøjede Kristus, og Adam-Kristus-typologien har i så fald fået sit mest ekstreme udtryk, men det er svært at afgøre, præcis hvad meningen er, fordi teksten er så kortfattet. Det legeme, som Gud har iklædt sig "fra" Adam, forstås bedst sammen med de to andre recensioner som det samme menneskelegeme, altså "fra" Adams slægt, som han også iklædte sig ved inkarnationen $(3,1)$, hvilket også gøres helt klart i recension 3 (se afsnit om recensionerne nedenfor). Spørgsmålet er, hvad der ligger i, at Adam ophøjes og gøres til en gud.

Indtil Robinsons afhandling i 1982 var TestAd oftest blevet anset i forskningen som enten et stykke gnostisk litteratur eller udtryk for en stærkt heterodoks kristendom (Robinson 1982, 19-43). Det skyldes ikke mindst forestillingen om Adams guddommeliggørelse, som Robinson kalder for skriftets "most striking doctrinal feature", ${ }^{29}$ men denne forestilling kan udmærket forstås inden for en mere gængs, ortodoks teologi, nærmere bestemt i forbindelse med den østlige kristendoms centrale forestilling om theosis, den troendes guddommeliggørelse. Denne lære hænger nøje sammen med inkarnationsdoktrinen (jf. Athanasius: "For han blev menneske, for at vi måtte guddommeliggøres", De Inc. Verbi 54,3) samt læren om gudbilledlighed og en ontologisk frelseslære. At menneskets frelse forstås som en helbredelse i forbindelse med den tabte gudbilledlighed, er præmissen i adamlitteraturen men netop også et grundlag for den østlige kristendom, hvor kristusbegivenheden virker "ontologisk" til helbredelsen ved hjælp af Jesu lære og i kraft af påskebegivenhederne og åndens udgydelse.

Theosis er et udtryk for den grundlæggende forståelse, at det at blive kristen er begyndelsen på en udvikling, en frelsesproces, hvorigennem den troende allerede i dette liv kan få del i helbredelsen og kan

sene mss. af VitaAd. Se også Esther Casier Quinn, The Quest of Seth for the Oil of Life (Chicago: The University of Chicago Press, 1962), 86ff.

29. Stephen E. Robinson, "Adam, Testament of", The Anchor Yale Bible Dictionary, red. David N. Freedman (New York: Doubleday 1992), bd. 1, 68. 
blive igennem nåde, hvad Gud er af natur. Man afklæder sig "det gamle menneske" og iklæder sig "det nye", hvorved man nærmer sig gudbilledligheden (Kol 3,10), ligesom man vil "tage del" i den guddommelige natur (2 Pet 1,4), fyldes med Guds fylde (Ef 3,19), blive herliggjort og en Guds søn ligesom Kristus (Rom 8,9-19.30; Gal 4,57) og sandelig blive en gud (Joh 10,34; Sl 82,6).

Eftersom her er tale om apokalyptisk litteratur med eskatologiske åbenbaringer skal vi forvente, at den strengt kronologiske fremstilling er veget til fordel for en tematisk fremstilling med kun udvalgte elementer, der indrammer og belyser ét eller flere aspekter eller temaer. ${ }^{30}$ Gud giver i 3,3 et lille oprids af hele frelsesplanen i tre dele ("For din skyld ..."), og det tidsmæssige spring i beskrivelsen direkte fra Golgata til den nye kosmogenese er et udtryk for kristusbegivenhedens sammenhæng med gudsrigets indstiftelse. ${ }^{31}$ Passagen med Adams ophøjelse og guddommeliggørelse følger lige efter opridset som en videre uddybning, og selvom det ser sådan $\mathrm{ud}$, beskrives der heller ikke her en snæver kronologisk sammenhæng mellem kristusbegivenheden og Adams frelse, men i stedet den virkningsmæssige sammenhæng. Måske spiller også motivet om "plyndringen af Helvede" - forestillingen om Kristus i dødsriget, der besejrer døden og tilvejebringer sjælenes frelse - ind her ligesom i de beslægtede skrifter Skattehulen (54,1-3) og Adams Kamp (IV, 5), men det er først og fremmest den ontologiske frelseslære, der kommer til udtryk: Adams frelse vil ske i kraft af, at Gud har oprejst et adamslegeme fra døden. Adam-Kristus-typologien fornemmes i teksten, og at Adam skal ophøjes til den højre side i himlen, kan endvidere være en "kristologisk" måde at give udtryk for den himmelske særstilling, som Adam (på linje med de andre patriarker) ofte gives både i og uden for adamlitteraturen. I den primære adamlitteratur er det en del af Guds løfte til Adam, at han skal indsættes i sit herredømme på den faldne Satans trone i Paradis (ApkMos 39,2; VitaAd 47,2). I Abrahams Testamente kap. 11 sidder Adam på en gylden trone uden for himlens første port, og i Evas kryptiske drøm i det armenske skrift Adams Død placeres han på en trone i himlen (v. 22).

I Skattehulen 2,12-25 iscenesættes Adam på baggrund af Gen 1,26 som en proto-Kristus ved sin skabelse, hvor han sidder på sin trone med en herlighedskrone som hersker og herre over alt det himmelske og jordiske, og han gives af Gud at være konge, præst og profet.

30. Geert Hallbäck, "How to read an Apocalypse”, Studia Theologica 47 (1993), 91-100 (92).

31. Den kristne adamlitteratur er generelt karakteriseret ved en 'påbegyndt eskatologi', hvor kristusbegivenheden er både endetidens begyndelse og klimaks. Jf. også TestAd 3,1: "Gud vil komme til verden efter tiderne". 
Ved sin dåb langfredag under Golgata (hvor han ligger begravet) får Adam sit kongedømme tilbage sammen med præsteskabet og profetien $(50,15)$, men pointen er her at slå fast, at det er den dag, hvor disse tre ting tages bort fra jøderne, der hidtil har forvaltet dem, så de nu overgår retsmæssigt til de kristne $(48,29 ; 50,15)$. Adams særstilling, inklusiv hans kongedømme, bliver altså i dette skrift implicit et udtryk for de kristnes særstilling, og dette forhold kan lige så vel gøre sig gældende i TestAd. Hans efterkommeres himmelske herredømme i TestAd 3,3 kan derfor også være det, der loves til Adam personligt med hans ophøjelse til højre side og guddommeliggørelse. Ifølge Matt 25,33 vil gudsrigets arvinger blive stillet på højre side af Kristi trone, når han vil komme og skille fårene fra bukkene, og i forskellige sammenhænge tales der i Det Nye Testamente om de helliges egne himmelske troner (Matt 19,28; Luk 22,29-30; Åb 3,12; 20,4). Blandt andet 2 Tim 2,12 fortæller, at de troende skal "herske" med Kristus, ligesom man ifølge Paulus er medarving med Kristus ved adoptionen gennem troen og ånden.

Til sidst i TestAd 3,4 uddyber Gud Adams frelse yderligere: "Og jeg vil tage gaven fra [træet] og genoprette dig og dit afkom, for det er himlens retfærdighed". Det er et gæt, at der skal stå "træet" i lakunen (jf. noten til oversættelsen), men det uddybes altså endeligt, at Adam og hans afkom kommer til at dele skæbne, hvilket netop indikerer, at ligesom Adam skal også hele menneskeslægten blive guder og sidde på højre side ligesom Kristus, altså "herske" i den nye himmel, jf. 3,3.

Rent teknisk vil frelsen tilsyneladende ske både i sammenhæng med påskebegivenhederne og denne "gave", og her er det muligt at se en liturgisk substruktur. I østlig kristendom spiller sakramentet krismering en vigtig rolle i forbindelse med dåben. Det svarer til den vestlige kristendoms konfirmation, men hvor konfirmationen er blevet adskilt fra dåbsritualet, foretages krismering i direkte forlængelse af dåben i form af en salvning med olie. Med ordene "seglet af Helligåndens gave" "bekræftes" dåben med denne olie, og den troendes deltagelse i påskebegivenhederne og modtagelse af Helligånden er fuldendt, hvorpå theosis nu kan realiseres. Der er grund til at forstå Adams "to-delte" frelse med henholdsvis påskebegivenhederne og "gaven" i takt med denne østlige sakramentelære.

Sammen med forestillingerne om salvning med Helligånden (Luk 4,17; ApG 10,38; 2 Kor 1,21-22) og åndens besegling (2 Kor 1,22; Ef 1,13 ; 4,30) bygger sakramentet krismering på Apostlenes Gerninger, hvor Helligånden betegnes som en "gave" (2,38; 8,20; 10,45; 11,17), der gives til den troende ikke gennem dåben men ved en separat håndspålæggelse efter dåben (8,14-17; 19,1-6; også 2 Tim 1,6-7). I Efeserbrevet betegner "gaven" selve frelsen $(2,8)$, idet Gud har "op- 
rejst" de troende sammen med Kristus og "sat os med ham i himlen" (Ef 2,6). Adam-Kristus-typologien udfoldes i Rom 5, hvor Paulus belyser omfanget af Guds nåde ved at modstille Adams overtrædelse med "gaven" som den forsoning, Gud nådigt har foranstaltet, og "dem, som modtager mangfoldigheden af nåden og af gaven og af retfærdigheden, skal herske i livet ved én, Jesus Kristus" $(5,17) .{ }^{32} \mathrm{I}$ Rom 6,23 er "Guds gave evigt liv". For så vidt den uheldige lakune $\mathrm{i}$ TestAd 3,4 gemmer på "træet", kan "gaven" betyde frugten fra livets træ, der vil give Adam (og hans afkom) evigt liv og dermed gøre ham til en gud, jf. Gen 3,22. Det er i den forbindelse påfaldende, at recension 2 på dette sted har en helt anden passage, hvor Adam forklarer til Set, at ved figenfrugten "skal livet komme til mig og mine børn" ved tidernes ende.

Robinson oversætter passagen ud fra den forståelse, at lakunen gemmer på గm\ ("Gud"): "And I will receive favor from God" (Robinson 1983, 994). Dette er problematisk, først og fremmest fordi fortællesubjektet umotiveret er skiftet væk fra Gud (til Kristus?), men også fordi ordet r אحח ד ("gave") dårligt kan oversættes til favor.

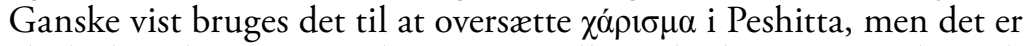
altid i betydningen "(nåde)gave", og alle steder bruges et andet ord,

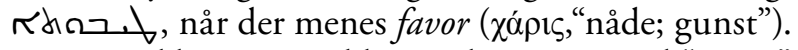

Derimod kan vi uproblematisk oversætte til "gaven" med adskillige fortolkningsmuligheder, der alle på en eller anden måde indbefatter Guds givne frelse. Der er imidlertid flere forhold, der peger på, at passagen henviser mere specifikt til åndens udgydelse, og at "gaven" bedst forstås som Helligåndens gave, der effektuerer Adams theosis. Løftet til apostlene om at skulle "døbes med Helligånden" (ApG 1,5) opfyldes med åndens udgydelse, der beskrives i ApG 2,33 i et vers, der minder særdeles meget om Test $A d$ 3,4 både sprogligt og indholdsmæssigt, og sammen med Peshitta indskyder alle syriske tekstvidner endvidere ordet "gave" i dette vers: "Og det er ham, der blev ophøjet til Guds højre side, og han modtog løftet fra Faderen om Helligånden, og han har udgydt denne gave, som, sandelig, I ser og I hører."

Sakramentet krismering kan tidligst spores til det 4. århundrede i liturgierne i De Apostolske Forfatninger (Bog 7, kap. 44) og i De Mystagogiske Katekeser, der traditionelt tilskrives Kyril af Jerusalem. I sidstnævnte tales der om, at de kristne er "kristus'er", og det beskrives, at ligesom Kristus kom op fra Jordanfloden og blev salvet med Helligånden, således bliver også den kristne efter at være kommet op fra dåbsvandet salvet med olien (III,1), og den er "Kristi gave,

32. Modsat de fleste græske tekstvidner har Peshitta ikke "gaven" i genitiv-forhold til "retfærdigheden". 
og ved Helligåndens tilstedeværelse bibringer den hans guddom"

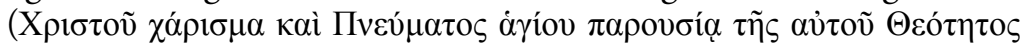

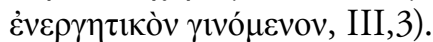

Der er naturligvis ikke noget træ involveret her. Men det er der i den primære adamlitteratur, hvis narrative univers Test $A d$ befinder sig i (jf. afsnit ovenfor om den litterære kontekst). Her er det nemlig et vigtigt tema, at "livets olie" fra det særlige "barmhjertighedens træ" (VitaAd 36; 42; ApkMos 9,3) skal gives til Adam, ikke når han ligger døende og dikterer sit "testamente", men ved tidernes ende, og i en nøglepassage forklares det til Set, at dette vil ske ved Kristi komme. Olien fra træet i denne passage kan forstås på én gang som både Helligånden og den hellige olie, kirken bruger i sin salvningspraksis, især ved krismeringen: "Guds søn skal selv komme og blive døbt i Jordans flod, og når han stiger ud af Jordans vand, da skal han salve alle, der tror på ham, med sin barmhjertigheds olie. Og barmhjertighedens olie skal være fra slægt til slægt for dem, der genfødes af vand og den Helligånd til et evigt liv" (VitaAd 42,3-4, cit. efter Hammershaimb 2001). Træet kan forstås som livets træ (jf. VitaAd 42,5), og med olien fra træet får de troende del i det evige livs herlighed allerede i dette liv. ${ }^{33}$ Det synes derfor rimeligt at gætte på, at lakunen gemmer på "træet", og at oversætte til "gaven fra træet". Ved at bruge ordet "gave" skabes forbindelsen mellem olien fra træet, åndens udgydelse og krismeringen, menneskets indgang til frelsen.

Alt i alt kan Profetien i Adams Testamente forstås som et lille østkristent stykke adamlitteratur, der er vedkommende for den troende på grund af de sakramentale og liturgiske undertoner (ligesom Timerne), og som ser ud til at gøre det, der er oplagt: at udtrykke teologien i den østlige kristendom i form af traditionerne fra adamlitteraturen, hvor Guds løfte til mennesket, Adam, bliver til løftet om hans theosis. Opfyldelsen sker i kraft af kristusbegivenheden, med påskebegivenhedernes helbredende virkning og med "livets olie" som "gaven", der skal gives til ham fra "barmhjertighedens træ". Denne olie er Helligåndens gave, på samme måde som den udgydes over enhver af hans slægt, der døbes og får denne gaves "segl”, krismeringens olie, til genoprettelsen af gudbilledligheden, theosis, som en kristus, en Guds søn, en medarving til gudsriget. Frelseshistoriens primus motor i adamlitteraturen er Guds kærlighed til sine hænders værk, sit konkrete billede, Adam, hvis efterkommeres frelse ofte nærmest synes at være en heldig bivirkning ved løftet til deres fader, og TestAd er ingen undta-

33. Forestillingen om salve til de kristne fra livets træ findes også i den pseudoclemmentinske Recognitiones 1,45 samt 5 Ezra 2,12 og Origenes, Contr. Cel. 6, 27. 
gelse: Det hele sker for Adams skyld. Således elskede Gud Adam, at han selv blev til et menneske, for at Adam måtte blive en gud.

\section{Adams og Evas døtre - og Kains og Sets slagter}

Kains hustru, som forudsættes i Gen 4,17, må - hvis Gud ikke havde skabt andre mennesker uafhængigt af familien Adam - være hans søster. Døtre af Adam og Eva omtales ganske vist ikke i de bibelske stamtavler, men heri adskiller Gen 4-5 sig ikke meget fra stamtavlerne i GT i øvrigt, der alle er fåmælte med hensyn til kvinderne, og Kains hustru er narrativt set ikke mere mystisk end Sets, som man aldrig hører nogen spørge efter.

Både jødiske og kristne fortolkningstraditioner har imidlertid sørget for at gøre det underforståede eksplicit og forklare, at Kain og Abel giftede sig med deres søstre; et eller flere navne på døtre af de to første mennesker nævnes i en række kilder $3^{34}$ kun syriske kilder kender navnet Lebuda, som både i TestAd 3,5 og i Skattehulen 5,19-21 forbindes med den tanke, at Abels død var et jalousidrab og ikke et spørgsmål om Guds modtagelse af offergaver.

Når 3,5 desuden forklarer den fremtidige syndflod med henvisning til "din bror Kains døtre", afspejler det en tolkning af Gen 6,2, hvor "gudesønnerne og menneskedøtrene" forstås som henholdsvis Sets slægt og Kains slægt - og hvor man altså afviser den ældre forestilling, kendt fx fra 1 En 6-7, om seksuelle relationer mellem engle og mennesker. En tolkning på linje med 1 Enok blev uproblematisk videreført af kirkefædre som Justin Martyr, Irenæus og Klemens af Alexandria, men kom på et tidspunkt i miskredit. Den ældste bevidnelse af den tolkning, som Test $A d$ her afspejler, angives gerne at foreligge hos Julius Africanus..$^{35}$ Julius formodes at have overtaget tolkningen fra syrisktalende kristne (Klijn 1977, 64) ${ }^{36}$ og hvis Robinsons date-

34. Louis Ginzberg, The Legends of the Jews (Baltimore: Johns Hopkins University Press 1998), I 108-09, V 138-39. James L. Kugel, Traditions of the Bible: A Guide to the Bible as it was at the Start of the Common Era (Cambridge: Harvard U.P. 1998), 148-49. John Byron, Cain and Abel in Text and Tradition: Jewish and Christian Interpretations of the First Sibling Rivalry, Themes in Biblical Narrative 14 (Leiden: Brill 2011), 27-29.

35. Se fx Albertus F.J. Klijn, Seth in Jewish, Christian and Gnostic Literature, NTSup 46 (Leiden: Brill 1977), 61-62.

36. Sebastian Brock betegner tolkningen som "the dominant understanding ... in Syriac writers of all periods" ("Jewish Traditions in Syriac Sources”, JJS 30 (1979), 212-32; 226), og den findes da også i utvetydig skikkelse i 4. århundrede hos de ældste 'ortodokse' syriske kirkefædre Afrahat (XIII 5; XVIII 9, jf. Peter Bruns (1991), 318; 438) og Efrem ("Hymner om Paradiset" 1,11 og adskillige andre steder, jf. Sebastian Brock, St. Ephrem the Syrian: Hymns on Paradise (Crestwood NY: St. Vladimir's Seminary Press 1990), 81-82). Derimod har en endnu ældre, men mere teologisk omstridt, syrer som Bardesan ingen vanskeligheder med tanken om engle- 
ring af Test $A d$ til midten eller slutningen af 3. århundrede holder stik, kan vi altså med denne tekst være mindst lige så tæt på traditionens kilde som hos Julius.

\section{Andre recensioner og versioner}

Som nævnt ovenfor findes den syriske tekst $\mathrm{i}$ to andre recensioner end den, der er oversat her. Recension 2 adskiller sig ved ikke at indeholde dagens timer, men til gengæld er det i det ene af manuskripterne i denne gruppe, at man finder den del af teksten, der er blevet kaldt Hierarkiet, og som fortæller om de himmelske magter og deres roller i verden. Recension 3 har både nattens og dagens timer, men med dagen først. Desuden optræder der her en introduktion, der eksplicit forbinder Timerne med Adam - det fortælles, at da Adam blev syg og skulle til at dø, fortalte han Set, hvad Gud fortalte ham om dagens og nattens timer dengang, da han også blev sat til at give dyrene navne. Efter Profetien indeholder recension 3 endvidere i forlængelse af omtalen af gaverne, som skal gives til Guds søn, en kort notits om, hvordan Davids salmer nøje har forudsagt alt dette.

Vi har ovenfor nævnt, at recension 2 identificerer den forbudte frugt som en figen. Der er talrige andre mindre og større afvigelser mellem recensionerne mht. den præcise ordlyd, rækkefølge osv. i Timerne, og mht. indholdet i Profetien. Her skal kun kort nævnes nogle af de mere interessante fra sidstnævnte: I recension 2 siges det, at det er Messias, der skal komme til verden, og ikke Gud $(3,1)$, og ligeledes er det Messias, der taler til Adam i Paradis (3,2). I 3,3 er det Eva, som Adam klandres for at have lyttet til, frem for slangen som i recension 1. ${ }^{37}$ Til forskel fra recension 1 , der taler om, at Adam skal sættes på guddommelighedens højre side, bruger recension 2 her første person med Messias som den talende. Derefter omtaler denne recension figenen som den frugt, der bragte Adam til fald (se ovenfor).

I recension 3 er der bl.a. en udvidet skildring af, hvordan Gud vil smide Adam ud af Paradis, bøje hans ryg og få hans knæ til at ryste af alderdom, inden han skal overgives til døden $(3,2)$. Gud beskriver

nes rolle, når han i en diskussion om viljens frihed argumenterer med, at "hvis englene ikke havde besiddet fri vilje, ville de ikke have haft samleje ( 9 a dadr) med menneskedøtrene, så de syndede og faldt fra deres plads", H.J.W. Drijvers, The Book of the Laws of Countries: Dialogue on Fate of Bardaișan of Edessa (Assen: Van Gorcum 1965), 14.

37. Det skal her bemærkes, at den eneste forskel på "Eva” og "slange” på syrisk er et enkelt yod. 
over for Adam sit inkarnationslegeme som "dit legeme" $(3,3)$, og han vil oprejse og ophøje "det legeme, jeg har modtaget fra dig" $(3,4)$, men Adam selv forklarer til Set, at Gud vil oprejse og ophøje det legeme, "han har modtaget fra dig" $(3,4)$, og at han vil iklæde sig "vores legeme" $(3,1)$. Gud vil altså ophøje et legeme fra Adams slægt til højre side, og ligesom i recension 2 siges det ikke, at Adam skal ophøjes til den højre side. Rækken af udsagn, der indledes med "for din skyld" i 3,3, er betragteligt udvidet i recension 3, bl.a. med omtale af Jesu dåb, faste i 40 dage, korset, piskningen, eddiken osv. Efter omtalen af ophøjelsen af den opstandne krop $(3,4)$ indeholder recension 3 endvidere en direkte formaning til Set (og tilhørerne) om at overholde Guds bud. I 3,5 er der en forskel i tidsregningen - hvor recension 1 og 2 taler om 6000 år, står der 10.000 åruger i recension 3.

Af interessante afvigelser i nogle af de øvrige overleverede versioner skal her nævnes følgende: Den græske version omfatter kun Timer$n e .^{38}$ Her optræder dagens timer først, og der er en del afvigelser fra den syriske tekst. Det mest påfaldende er, at hver time er forsynet med et navn, skrevet med hebraiske bogstaver, ligesom der også optræder hebraiske bogstaver nogle andre steder i teksten. Det er imidlertid ikke hebraiske ord, der gengives, men græske (i de tilfælde, hvor det overhovedet er muligt at få mening med dem). Noget tilsvarende findes også i den ene form af den armenske version..$^{39}$ Her har hver time også et mystisk/magisk navn, og det fremhæves for hver time, hvad den er gavnlig for, især mht. fremstilling af talismaner med forskellige magiske formål. Der findes også en anden form på armensk, som kun omfatter nattens timer og ikke har navnene og de magiske bemærkninger med. ${ }^{40}$ En interessant tilføjelse i nattens første time i denne tekst er et citat fra Fil 2,10 om, at de himmelske, jordiske og underjordiske skal bæve, som en forklaring på den tanke, at dæmonerne skal lovprise Gud.

Den arabiske og etiopiske version lægger sig tættest op ad den syriske recension 3, men der er talrige mindre afvigelser. ${ }^{41}$ Her skal blot nævnes følgende: I den etiopiske er det ikke Gud selv, men "Gud den Højestes ord", der vil komme til verden (3,1). I 3,2 gengives "efter mange år" med "efter kort tid"! I 3,3 gengives "efter en kort tid" med

38. Den græske tekst med oversættelse findes i Robinson (1982), 105-133.

39. Michael E. Stone, Armenian Apocrypha Relating to the Patriarchs and Prophets (Jerusalem: The Israeli Academy of Sciences and Humanities 1982), 39-80.

40. Michael E. Stone, Armenian Apocrypha Relating to Adam and Eve (Leiden: Brill 1996), 167-173.

41. Begge versioner findes i Carl Bezold, "Das arabisch-äthiopische Testamentum Adami”, Theodor Nöldeke zum siebzigsten Geburtstag, red. Carl Bezold (Gießen: Verlag von Alfred Töpelmann 1906), 893-912. 
"efter fem og en halv dag" (jf. ovenfor om Skattehulen). I forlængelse af opremsningen af "for din skyld" i 3,3 slås der over i en lovprisning, og eftersom den følger umiddelbart efter "Og alt dette for din skyld Adam", lyder det, som om det er Adam, der lovprises: "Til hvem der er lovprisning og herlighed og magt og ære og tilbedelse og lovsang sammen med hans far og den hellige ånd”. Enten identificeres Adam her i udpræget grad med Kristus, eller også må man antage, at der er faldet noget ud af teksten på dette sted.

Den arabiske version har nogle af de samme særtræk som den etiopiske (som givetvis har udgangspunkt i den arabiske). I 3,3 gengives "efter en kort tid" med "efter fem og en halv af mine dage". Den påfaldende lovprisning, der findes i den etiopiske version, er der også på arabisk. Her er den imidlertid ikke knyttet til Adam, men til Gud (der står "og til hans søn og til den hellige ånd”). Desuden har den arabiske version i 3,4 en understregning af, at ophøjelsen af den opstandne krop skal ske uden adskillelse: "jeg vil oprejse den krop, som jeg har taget fra dig, og jeg vil føre den op med mig uden adskillelse fra mig og sætte den ved den højre side af min guddommelighed, og jeg vil gøre dig til en gud, som du ønskede”. 